\title{
Building Collaborative Governance on Services Delivery for Children
}

\author{
Farida Nurani*, Wike \\ Public Administration, Administrative Science Faculty \\ Brawijaya University \\ Malang, Indonesia \\ *farida_fia@ub.ac.id, wikebangun@gmail.com
}

\begin{abstract}
Good governance will be achieved if collaborations, partnerships and networks among stakeholders of governance exist particularly on certain issues that requiring attentions from governments, private sector and civil society. The collaboration among stakeholders for providing services for children is being more important; this is thus necessary to know how to build Collaborative Governance to Child Services with all its challenges and supports. This paper is aimed to identify and to analyze in how build the collaborative. This is a qualitative study that used a secondary data and review of literatures to achieve paper's goal as well conducted some journals and government reports on policies and programs to support children services as a way to obtain research finding in virus outbreaks situation currently. This study-identified stakeholder has a pivotal role to deliver the services for children, however there is still lack of collaborative synergic among stakeholders as they are still working institutionally independent. Slightly this finding is not in line with Emerson and Nabatchi that interdependency and dynamic is important to build the good collaborative among stakeholders in term of delivering services particularly for children. This result of research recommend to strengthen all institutions that focusing on children services and to integrate different services in one taskforce in order to give a good service provider for children in Indonesia. The integrated services are provided to children from early childhood so the children can be successful to grown up until young adults, and to fulfill the children' basic rights as normal and healthy children.
\end{abstract}

Keywords-collaborative governance, services delivery for cildren

\section{INTRODUCTION}

Based on the Decree of the Minister of Social Affairs Number 15A / Huk / 2010, concerning General Guidelines for Child Social Welfare Programs, the Child Social Welfare Program (CSWP) has begun to be implemented [1]. As for the purpose of child protection, it is intended to ensure the fulfillment of children's rights so that they can live, grow, develop and participate optimally in accordance with human dignity and protection from violence and discrimination. PKSA is intended as a directed, integrated and sustainable effort carried out by the government, local government and the community in the form of social services to meet children's basic needs, which include assistance or subsidies for basic needs, accessibility of basic social services, strengthening parents or families, and strengthening Child social welfare institutions.

In the concept of governance, the government is one actor and not the sole actor and is not always the most decisive actor. Governance will only be realized if there are collaborations, partnerships and networks between elements of governance, namely the state, the private sector and civil society. Where the network between these elements is an important feature of the development of modern organizations today, whether private or public organizations. According to Ansell and Gash [2], collaborative governance is a series of arrangements in which one or more public institutions directly involve non-state stakeholders in formal, consensus-oriented and deliberative policy-making processes that aim to make or implement policies. Public or manage programs or assets. Furthermore, they said that it is "a governing arrangement where one or more public agencies directly engage non-state stakeholders in a collective decision-making process that is formal, consensusoriented, and deliberative and that aims to make or implement public policy or manage public programs or assets". From this description, it can be understood that collaborative governance is an arrangement that regulates one or more public institutions that are directly involved with non-public stakeholders in a formal, consensus-oriented, and deliberative collective decision-making process that aims to make or implement public policies or manage programs or public assets. Another opinion was expressed by Emerson and Nabatchi [3], that collaborative governance does not emphasize the government as the initiator.

Collaboration between stakeholders in providing services for children is important, so it is necessary to know how processes and activities involve stakeholders with an emphasis on coordination based on consensus and deliberative in providing services for children. This research addresses the enabling and constraining factors that underpin interorganizational collaboration in Child Welfare and Protection services in Kota Malang, one of biggest cities in East Java province, along with how the organizations, either private or public, work together for particular purposes by delivering 
services for children. These argue that although a core set of organizations may be identified as necessary for collaborative to operate in a successful, sustainable manner; greater attention should be paid to how these organizations interact with one another on the ground, given schemes' particular scope and scale of objectives.

Methodologically, the issue of child protection raises questions; what efforts will be made to protect children in the context of collaborative governance and how to build collaborative governance in providing services for children's rights.

\section{METHODS}

Based on the background of the problem and research objectives, this study used a qualitative-descriptive approach. By emphasizing on processed data from content analysis from some journals, government reports, and secondary data in seeing how services are implemented for children through a collaborative governance approach.

\section{RESULTS AND DISCUSSION}

\section{A. Collaborative Governance}

In general, it is explained that Collaborative Governance is a process in which various stakeholders are involved to carry the interests of each agency in achieving common goals. According to Ansell and Gash [1] defines Collaborative Governance is an arrangement that regulates one or more public institutions to directly engage with non-public stakeholders in a formal, consensus-oriented, and deliberative collective decision-making process that aims to create or implement public policies or manage public programs or assets. There are 6 characteristics of collaborative governance:

- The forum is initiated or implemented by public institutions and actors in public institutions.

- Participants in the forum also include non-public actors.

- Participants are directly involved in decision making and decision making and decisions do not have to refer to public actors.

- Forums are formally organized and meetings are held together.

- The forum aims to make decisions based on mutual agreement, in other words the forum is consensusoriented.

- Collaboration focuses on public policy and public management.

The definition of Collaborative Governance described by Agrawal and Lemos in Emerson et al. [4], explains that the definition of Collaborative Governance is not only limited to stakeholders consisting of government and non-government but also formed by the existence of "multi-partner governance"which includes the private sector, society and civil society and is built on the synergy of stakeholder roles and hybrid planning such as public-private and private-social cooperation.

Collaborative Governance is based on the objective of jointly solving certain problems or issues from the parties concerned. These parties are not limited to government and non-government agencies, because in the principles of good governance, civil society is involved in the formulation and decision-making. Cooperation is initiated based on the limited capacity, resources and networks of each party, so that cooperation can unite and complement various components that encourage the successful achievement of common goals. In the formulation of goals, vision-mission, common norms and values in cooperation, the position of each party is equal, namely having the authority to make decisions independently even though it is bound by mutual agreement [5].

According to Stephan Balogh in Purwanti [5], Collaborative Governance has three dimensions, namely system context, drivers, and collaboration dynamics:

- The first dimension is depicted with the outermost box which is the scope / system context that covers it. This first dimension has 7 elements, namely:

- Resource Condition,

○ Policy and Legal Framework,

○ Level of Conflict / Trust (Conflict between interests and levels of trust),

○ Socio-economic; health; culture; and variety (Portrait of Conditions),

- Prior failure to Address Issues,

○ Political dynamics / power relations, and

- Network connectedness.

- The second dimension is part of the concept of Collaborative Governance which consists of the dynamics of collaboration and collaborative action. Current conditions at the outset of collaboration can either facilitate or prevent collaboration between stakeholders and between agencies and stakeholders, many frameworks tend to confuse context and system conditions with specific drivers of collaboration.

Conversely, a framework that separates contextual variables from important drivers, without encouragement to collaborate will not be successful This second dimension has 4 components, namely:

- Leadership, refers to a leader who can take the initiative to start and help prepare resources.

- Consequential incentives, leading to both internal (resource, interest, or opportunity issues), and external (crises, threats, situational / institutional opportunities). 
- Interdependence, a condition when individuals and organizations cannot achieve something with the efforts and capacity of one party.

- Uncertainty, uncertainty is the main challenge in managing public problems.

- The third dimension is the dynamic of collaboration which consists of three components, namely Principled Engagement, Shared Motivation, Capacity for Join action.

\section{B. Child Protection}

One of the instruments used in child protection is law. Legal protection for children can be interpreted as an effort to protect the law against various violence and children's rights as well as various efforts related to children's welfare [6]. There are several concepts and definitions that have been put forward regarding child protection. Child protection according an effort to create conditions and situations that allow the implementation of children's rights and obligations humanely [6].

Children are human beings who are rights bearers, namely everything that has rights and obligations which are called legal subjects. The definition of a child is regulated in Article 1 number 1 of Law 35 of 2014 concerning Child Protection which reads as follows: "A child is someone who is not yet 18 (eighteen) years old, including children who are still in 35 Year 2014 concerning Child Protection states that: "Child Protection is all activities to guarantee and protect children and their rights so that they can live, grow, develop and participate, optimally according to with human dignity and protection from violence and discrimination ". To fulfill rights for children, government has a pivotal role to provide some services. This study found that there are some government agencies work based on basic needs of Indonesian children. Those are 7 agencies including Office of Woman Empowerment, Child Protection, and the P2TP2A Office, Office of Education, Office of Social Affairs, Office of Health, Office of Demographic Affairs. Civil Registration Office, Office of Labor. Each of agency work on own task resulting on lack of well performing in term of coordinating to provide services, and independently working. Slightly this finding is not in line with Emerson and Nabatchi [3] that interdependency and dynamic is important to build the good collaborative among stakeholders in term of delivering services particularly for children.

Law No.35 of 2014 concerning Child Protection was formed with the aim of ensuring that children meet the needs of children in order to live, grow, develop and participate optimally in accordance with human dignity and protection from violence and discrimination, the realization of Indonesian children who are qualified, noble, and prosperous. A human being has human rights which have been promulgated by the State to its citizens, meaning that a human being has human rights since being cleansed, as well as ana. A child has slightly different rights from an adult according to the laws in force in Indonesia.

\section{CONCLUSION}

Collaborative Governance in the context of protecting the implementation of child protection policies involves 7 agencies or institutions with roles including: Office of Woman Empowerment, Child Protection, and the P2TP2A Office, Office of Education, Office of Social Affairs, Office of Health, Office of Demographic Affairs. Civil Registration Office, Office of Labor. However, each agency is still not optimal to cooperate between agencies. In working together to realize the dream of providing better services to children. This is due to the ego-sectoral of each agency and considers that the issue of child protection is not a priority for the welfare of children. To build collaborative governance, child protection requires institutional strengthening for each related agency.

\section{REFERENCES}

[1] https://www.unicef.org/indonesia/topics/child-protection

[2] C. Ansel and A. Gash, Collaborative Governance in Theory and Practice. Berkeley: University of California, 2008.

[3] K. Emerson and T. Nabatchi, Collaborative Governance Regime. Washington: Georgetown University, 2015.

[4] K. Emerson, T. Nabatchi, and S. Balogh, "An integrative framework for collaborative governance," Journal of public administration research and theory, vol. 22, no. (1), pp. 1-29, 2012.

[5] N.D. Purwanti, Collaborative Governance (Kebijakan Publik dan Pemerintahan Kolaboratif, Isu-Isu Kontemporer). Yogyakarta: Center for Policy \& Management Studies, FISIPOL UGM, 2016.

[6] Gosita, Masalah Perlindungan Anak. Jakarta: Akademi Pressindo, 1989. 